Volumen 16 Número 3, Julio - Septiembre 2021, pp. 1-22, e634

THE ECONOMICS AND FINANCE EFFECTS OF THE COVID-19 PANDEMIC Editor: Dr. Ignacio Perrotini

DOI: https://doi.org/10.21919/remef.v16i3.634

\title{
Initial Management of COVID-19 Outbreak in Mexico
}

\author{
Cinthya G. Caamal-Olvera1 - Universidad Autónoma de Nuevo León, México \\ Julio César Arteaga García² - Universidad Autónoma de Nuevo León, México
}

This paper analyzes the initial stage of the pandemic COVID-19 in Mexico. The objective is to test whether the contagion risk perception and the authorities' initial prevention messages influenced the COVID-19 deaths. We estimate longitudinal elasticities of deaths to confirmed COVID-19 cases by accounting for measurement error and endogeneity issues. We find that confirmed cases and poverty levels are endogenous. The limitation arises because of the underreported COVID-19 deaths. Our contribution is to identify an association with the individual and political risk perception to the number of COVID-19 deaths. The results show that municipalities with more confirmed cases aware of being in contact with another person affected by COVID-19 have fewer deaths. However, emergency management, federal and state, had weak effects of reducing the lethality rate. We infer that better individual risk awareness is an essential factor in reducing the number of deaths from COVID-19. JEL Classification: C23, H12, H75, I10, 054.

Keywords: COVID-19, Mexico, Lethality rate, emergency management, risk perceptions.

\section{Gestión inicial del brote de COVID-19 en México}

Este artículo analiza la etapa inicial de la pandemia COVID-19 en México. El objetivo es probar si la percepción del riesgo de contagio y los mensajes de prevención iniciales de las autoridades influyeron en el número de muertes por COVID-19. Estimamos las elasticidades longitudinales de las muertes a los casos confirmados de COVID-19 teniendo en cuenta el error de medición y los problemas de endogeneidad. Encontramos que los casos confirmados y los niveles de pobreza son endógenos. La limitación surge debido a que las muertes por COVID19 están subreportadas. La contribución es identificar una asociación de la percepción de riesgo individual y político con el número de muertes por COVID-19. Los resultados muestran que los municipios con un mayor porcentaje de personas conscientes de haber estado en contacto con otra persona afectada por COVID-19 tienen menos muertes. Sin embargo, la gestión de la emergencia, tanto federal como estatal, tuvo efectos débiles en la reducción de la tasa de letalidad. Inferimos que una mejor conciencia individual del riesgo es un factor esencial para reducir el número de muertes por COVID-19.

Clasificación JEL: C23, H12, H75, I10, 054.

Palabras clave: COVID-19, México, Tasa de letalidad, Gestión de emergencias, Percepciones de riesgo.

${ }^{1}$ Corresponding author. Av. Lázaro Cárdenas \# 4600 Ote., Fraccionamiento Residencial Las Torres, Monterrey, N. L., Mexico, C. P. 64930, Tel. +52-8183294150 Ext. 2414; cinthya.caamallv@uanl.edu.mx; https://orcid.org/0000-0003-02494027

2 https://orcid.org/0000-0002-4613-1677

* Source of funding for research development in Acknowledgements. 


\section{Introduction}

This article analyzes the mortality of the COVID-19 outbreak during the first four months for the Mexican urban metropolitan zones. More than $70 \%$ of deaths and confirmed cases in Mexico have occurred in these regions. To understand the early development of the outbreak in Mexico, we examine the evolution in deaths' ratio to confirmed cases, as one of the epidemiological criteria based on the World Health Organization (WHO 2020, May 12). The number of deaths might be a more accurate indicator of controlling the epidemic when the testing is low. According to Hasell et al. (2020), Mexico applied about 6.23 tests per thousand persons on July 17. We analyze the Mexican case by accounting for the heterogeneity among municipalities and evaluate the risk communication's effectiveness.

The idea is to obtain geographical, environmental, and economic factors inherent to the cities to understand the factors related to the pandemic's evolution over the first four months. We hypothesize that including the awareness of being in contact with COVID-19 patients makes people better assess their health risk once they become confirmed cases. Thus, people make better decisions that benefit their health outcomes, such as early treatment, and implement protective measures that limit the disease's spread, such as social distance, face mask use, and personal hygiene. We also account for political inclinations to identify differentiation on the COVID-19 risk perception (Bruine de Bruin, Saw, and Goldman, 2020), which discern protective behavior decisions. Bruine de Bruin and Bennett (2020) provide evidence that people are more likely to implement protective behavior if they perceive more significant risk.

Political factors may contribute to the disease's risk perception. Political polarization is associated with disagreements in preventive measures such as using a face mask and avoiding public spaces or crowds, according to the USA evidence of Bruine de Bruin, Saw, and Goldman (2020). The current Mexican President, Andrés Manuel López Obrador, won the 2018 elections, with most voters supporting his political success (53.19\%). The President is an influencer leader able to convince people to follow health advice and be vigilant to control the COVID-19 outbreak, given the uncertain information available at the moment. However President's actions and signaling messages were not consistent with the international recommendations, particularly when WHO characterized COVID19 as pandemic on March 11, 2020. We hypothesize that citizens received unclear messages that let them conclude and react differently, which could have triggered less cautious behavior to increase the risk of exposure to the COVID-19.

Our results provide elasticity of COVID-19 deaths to confirmed cases lower than the unity, which implies that the outbreak was not out of control for the first four months of the pandemic in Mexico. However, it reveals that an increase of ten percent in COVID-19 confirmed cases is associated with a six percent increase in deaths. We infer that people aware of being in contact with another person affected by COVID-19 internalize the risk they face at the early development of the symptoms and reduce deaths. This paper provides evidence consistent with Bruine de Bruin and Bennett's (2020) finding that emphasizes the need to assess associations between risk perceptions and protective behaviors. 
We contribute to the empirical literature that better risk awareness is an essential factor in reducing the number of deaths from COVID-19. We conclude that the most decisive risk perception indicator is the individual relative to the political factor. Still, there is a shared responsibility among national and subnational governments as well as the community to follow the public health recommendations to control the pandemic. The messages and actions must be consistent with communicating the uncertain and limited information available at the time. The first response is critical to contain an outbreak that raises concerns because it is a highly contagious virus not easy to detect, especially in poor regions where there are fewer opportunities to work from home. Under this scenario, the best response had to be cautious and prudent before underestimating the severity of the new coronavirus COVID-19.

The rest of the paper is organized as follows. Section 2 describes the government management to the COVID-19 pandemic at the early stage. Section 3 shows the development of the pandemic in Mexico. Section 4 describes the municipality factors related to COVID-19 lethality rates. Section 5 presents the methodology and empirical strategy. Section 6 presents the results, and Section 7 concludes.

\section{Uncertainty and early governments' response}

Guidelines and knowledge about the novel coronavirus COVID-19 came from the Chinese experience. On December 31, Wuhan's city reported 44 persons with viral pneumonia of unknown causes, and eleven persons were in critical condition. The next day, the Chinese government ordered the lockdown of the entire city. After ten days of research, the first genetic sequence for the novel coronavirus revealed a close relationship with SARS (Severe Acute Respiratory Syndrome) that occurred in China in 2002, and MERS (Middle East Respiratory Syndrome) that appeared in 2012 (Prompetchara, Ketloy, and Palaga, 2020). Available information suggested that the virus could cause severe illness in some persons as the mentioned coronaviruses. However, by that time, there was little information available on the source, modes of transmission, extend of infection, and countermeasures to prevent the COVID-19 outbreak in other parts outside China, WHO (2020, January 11).

The first guidelines published by WHO (2020, January 10) had the intention that authorities in each country identify main gaps and pointed out the importance of risk communication and community engagement (RCCE). Countries could design effective public health interventions to communicate what was known to control the disease's spread, WHO (2020, January 10). RCCE would help reducing the spread of misinformation, building trust, increasing the probability of following health advice, and minimizing the risk perception gap among the public and authorities and experts. Bruine de Bruin and Bennett (2020) emphasize the need to assess the relationship between risk perceptions and protective behaviors because people who perceive higher risks are more willing to implement more protective behaviors. In a politically polarized environment, prevention efforts are less effective when different sources provide different and confounding messages (Bruine de Bruin, Saw, and Goldman, 2020).

South Korea was an example of how to control a massive outbreak in three months. The key strategies to flatten the COVID-19 epidemiological curve were combine testing, early isolation, free treatment of positive cases, open and transparent communication to the public, and digital 
technologies without incurring lockdown measures as China applied. The South Korean population followed hygiene measures, self-quarantine, social distance and showed a high civic awareness level and voluntary cooperation (Lee, Heo, and Seo, 2020).

Most countries showed an increase in stringency measures in March, according to the data generated by Hale et al. (2020). China had the strictest rules according to the value of Oxford's stringency level. ${ }^{3}$ By April and May, Italy surpassed China as it applied more stringent measures. Mexico showed an increase in their controlling efforts on March 17, but lower than the United States of America (USA). When the USA approached the same stringency measures as South Korea, Mexico was behind. In March, Brazil started to follow more restricted measures to control the outbreak, while Mexico showed a stricter policy until April that lasted until May. After June, Mexico showed an index value below the stringent standards followed in Brazil but above the USA's standards, while Italy and South Korea imposed fewer restrictions.

\section{Development of the pandemic in Mexico}

The development of the COVID-19 pandemic raised questions of whether the governments and health care authorities took the best decisions given the uncertain and incomplete information they faced. The Mexican government has provided a website with information regarding COVID-19 deaths, cases, and other indicators. Chundakkadan and Ravindran (2020) point out that online information is essential to containing the spread by raising public awareness of the problem. The cultural, environmental, and socioeconomic heterogeneity across Mexican municipalities provide a source of variation to analyze the pandemic and the political actions due to differences in the national strategy messages. Unclear messages can trigger a less cautious behavior from the population to increase the risk of exposure to the COVID-19, and more cases and more deaths can occur. For the USA case, Bruine de Bruin, Saw, and Goldman (2020) found that individuals with different political inclinations, republicans versus democrats, have different risk perceptions and disagree on the importance of implementing preventive measures such as face mask use and social distancing.

In the morning daily press conference on March 16, 2020, the Mexican President informed 53 new confirmed cases and referred that majority of the COVID-19 patients cure spontaneously and that after recovery, they would be immune. ${ }^{4}$ At the end of the press conference, reporters asked if the President had taken the test and whether he would stop his massive events. President's answer was not to involve politics in a health emergency and follow medical recommendations. There were several questions on the Presidential activities. The official health speaker then claimed that it would be better for the President to suffer from Coronavirus because of the immunization. The speaker concluded by saying, "the President's strength is moral; he is not a contagious force... the President has the same probability of contagion as everyone else." The uncertainty regarding the severity and speed of contagion polarized opinions among the strategies to follow at the sub-national levels.

\footnotetext{
3 There are 18 indicators divided into four dimensions: containment and closure, economic response, health systems, and miscellaneous. More details https://covidtracker.bsg.ox.ac.uk/stringency-scatter

${ }^{4}$ https://presidente.gob.mx/16-03-20-version-estenografica-de-la-conferencia-de-prensa-matutina-del-presidenteandres-manuel-lopez-obrador/
} 
Several Mexican states' governments disagreed with the federal government's pandemic management and formed a group to coordinate local efforts to control the outbreak. The health authorities announced the first case on February 28. That same day, three northeastern states that share the USA border (Coahuila, Nuevo León, and Tamaulipas) announced joining into an allied group, later called Federalist Alliance (FA) counterweight the federal resource assignment decisions to manage the pandemic response. 5 These states united in treating patients, obtaining medical supplies, and dealing with the pandemic. They also took more stringent actions to contain the outbreak by suspending school activities one week before the national strategy set up on March 24, DOF (2020). Mexico then started phase 2 of the pandemic. More information regarding the cases and deaths came out, and more states joined the FA group. ${ }^{6}$ Michoacán and Durango, states in the Pacific and the North-center region, entered on April 24. In the Pacific region joined the FA group, Colima and Jalisco (May 15). From the Center region, Guanajuato joined on June 5, while Chihuahua, a northern state, on June 26. San Luis Potosí and Aguascalientes joined lastly on July 15. Governments of ten states have joined the FA group, integrated from political parties other than the President.

Mexico's lethality rate has been consistently high and increased steadily to reach a peak of $11.69 \%$ in June and a slight reduction to $11.10 \%$ on July 31, 2020, as Graph 2 shows. On average, Mexico's COVID-19 lethality rate is three times higher than the world, which declined from $4.14 \%$ to an estimated 3.53\%. The first WHO situated report indicated six deaths and 282 confirmed cases worldwide; figures mainly came from China. By the end of February, the report showed 86 deaths and 6,009 patients, of which 21 losses and 888 affected people were in Italy. Mexico reported its first death because of COVID-19 on March 18. Reports from mid-April set Spain as the European country with the largest number of cases. In May, the Americas replaced Europe as the region with the most infections but not in deaths. The report of July 31 detailed more than 668 thousand deaths and 17 million cases worldwide. The USA, Brazil, and Mexico led the continent in deaths and confirmed cases and coincided with their presidents' vision because they minimized the pandemic outbreak in the early stage. Graph 1 shows that Spain, the USA, and Brazil's lethality rates resemble the pandemic's world evolution, as they reached their highest value in May and started to show a reduction. However, Mexico did not show a decrease but a similar trend to Italy.

\footnotetext{
${ }^{5}$ https://www.nl.gob.mx/boletines-comunicados-y-avisos/pactan-gobernadores-del-noreste-creacion-de-protocolospor-riesgo-del

${ }^{6}$ https://www.infobae.com/america/mexico/2020/08/20/que-es-y-quienes-integran-la-alianza-federalista/
} 


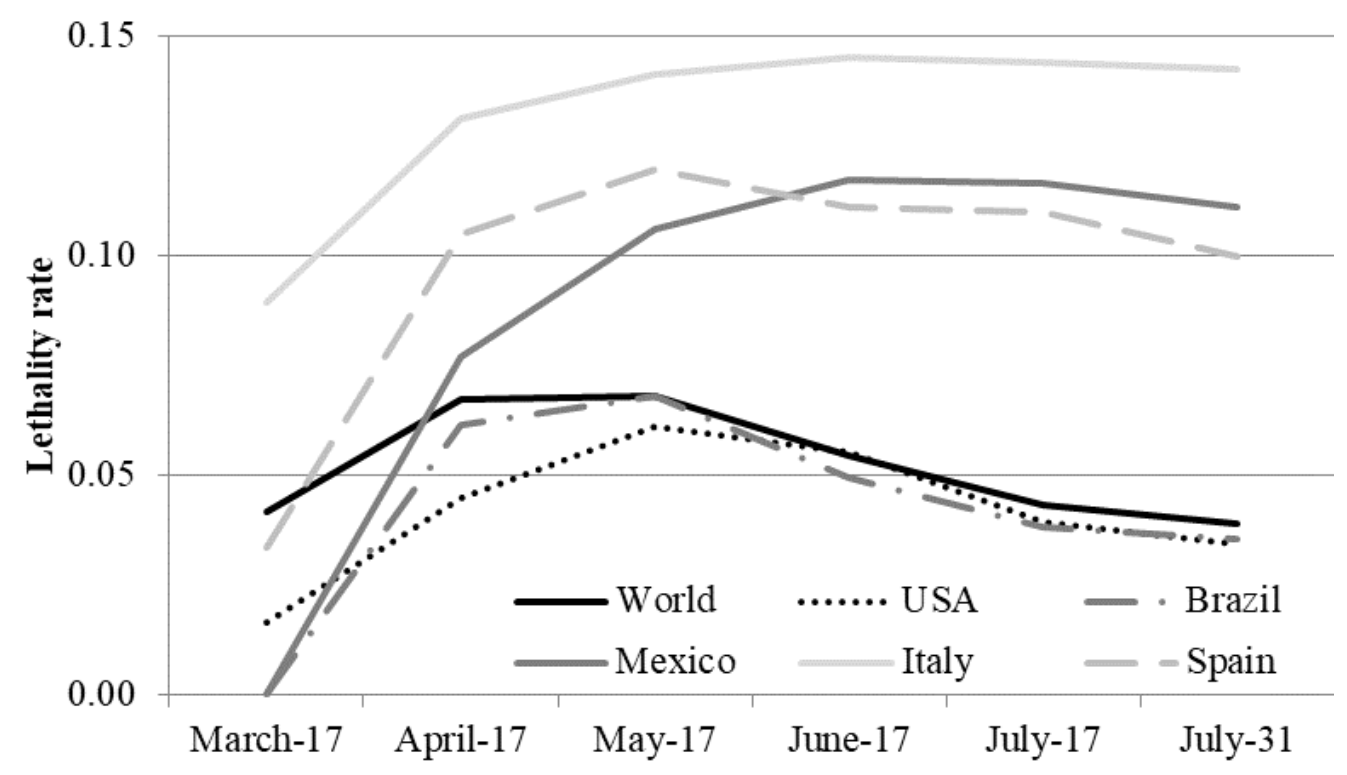

Graph 1. The evolution of the lethality rate: an international comparison during the early stages Source: Own elaboration with information from Situation Reports, WHO (2020).

One explanation for the high lethality rate in Mexico is the few COVID-19 tests performed. According to Roser et al. (2020), Mexico applied 71 daily tests per million people. Meanwhile, Italy performed 785 daily tests per million people on August 13, and Spain carried out 1,013 on August 6. According to Hasell et al. (2020), Mexico increased the testing from 0.03 per thousand on March 17 to 11.88 per thousand on September 17. The most considerable value of testing in Mexico is similar to the second-lowest testing in South Korea (10.38 per thousand, on April 17). The low testing and lack of reliable updated information resulted in under-reported daily monitoring of confirmed cases. There was also a delay in diagnosis confirmation of the sickness to assess the pandemic's real progress. Later scientific evidence from WHO (2020, April 2) revealed that asymptomatic COVID-19 affected people also could spread the disease, increasing the risk of contagion and without the possibility of tracing the contacts.

The evolution of cases and deaths is heterogeneous among Mexican states. Three states took at most ten days between reporting their first-case and the first-death. Half of the country's states took between 11 and 20 days, while Nuevo León took the most extended period of 80 days. Tlaxcala was the last state to inform its first case. The evolution of lethality rates also differed among Mexican states. Graph 2 shows that the lethality rate reached almost 29\% in Morelos at the end of May before it started to decline. Other states had not reached their peaks, as Chiapas and Aguascalientes kept a rising lethality rate. For the whole country, the lethality rate reached its peak in the second half of May. 


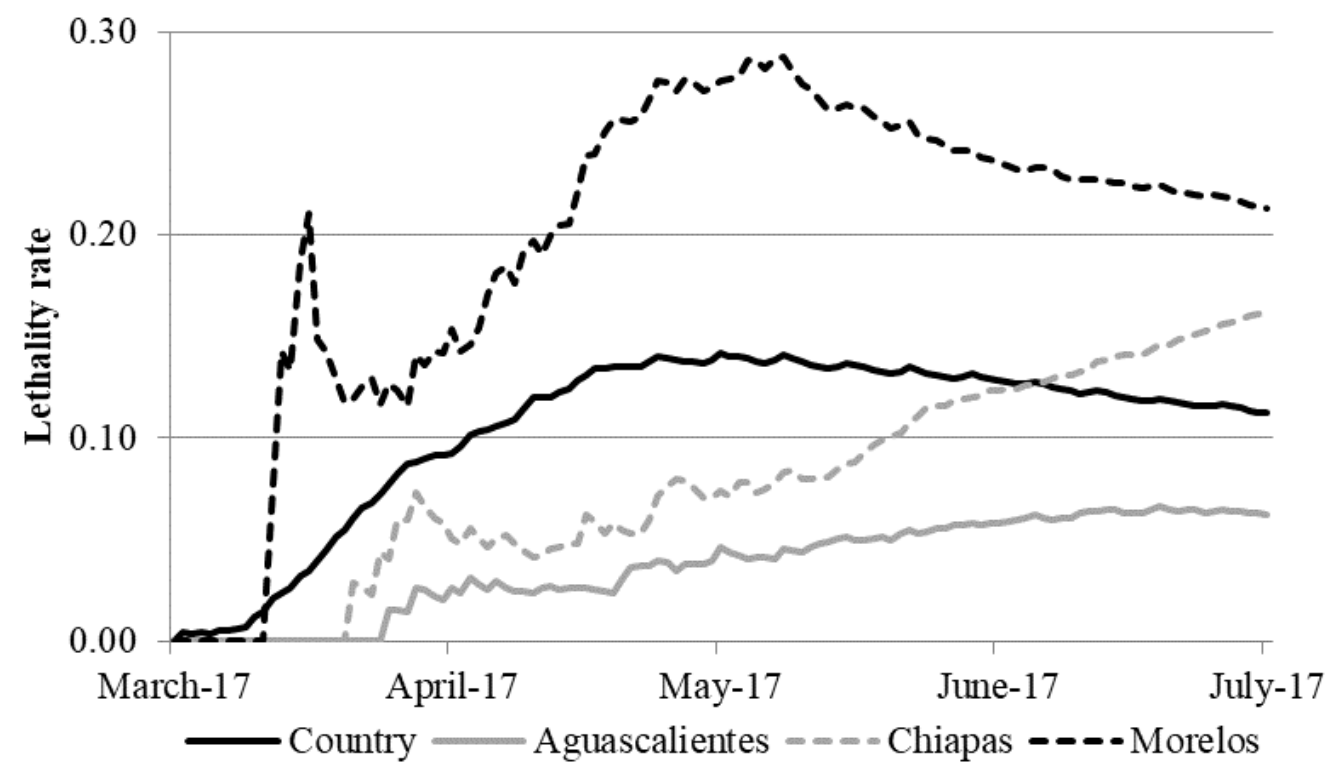

Graph 2. Evolution of the lethality rate: A national comparison

Source: Own elaboration with information of Secretaria de Salud (2020).

Graph 2 shows that the evolution and peak in the lethality rate within the country's states differ. It is not only because of the different times to identify the sickness but also because of the data's compilation. Secretaria de Salud updates information retroactively. For example, on April 24, Mexico had accumulated 1,221 deaths and 12,872 cases (a lethality rate of 9.5). However, on August 3 , the report indicates that by April 24, the country had accumulated 2,172 deaths and 19,963 cases (a lethality rate of 10.9). To limit the effect of information changes, for this graph, we use Secretaria de Salud (2020) database reported on August 3, considering only the accumulated cases and deaths until July 17. As the first death reported in Mexico occurred on March 18, we have information for four months.

\section{Municipality specific factors related to the lethality rate}

The urban municipalities in the metropolitan zones (MZ) share similar poverty levels and other timeinvariant variables, which are not dependent on the people's actions, such as geographical elements and environment. The MZ municipalities represent 17\% of the Mexican municipalities, account for $63 \%$ of the total population, and concentrate $78.8 \%$ of the total deaths. Table A1, in the Annex, shows the descriptive statistics and definitions of each time-invariant variables we include in this study. Travel restrictions, quarantine, protective behavior in medical care-seeking behavior, use of face masks, social distancing, and self-isolation were measures that drop the rate of transmission in China and South Korea (Li et al., 2020; Lee, Heo, and Seo, 2020). However, these measures represent challenges for some populations. Mexico is a country with high economic inequalities. According to the multidimensional poverty measurement estimated by CONEVAL, there are cities with very low poverty percentages, $4.4 \%$ as the minimum poverty level, and cities with large percentages, $83.3 \%$ 
as the highest poverty percentage. The average level of poverty across municipalities is $45.2 \%$ (Datamun Coneval, 2020b). This index measures the proportion of people with income below poverty line that have also deprivation of education, health, social security, food security, services, and conditions of the house. Therefore, the level of poverty may impede following the recommendations of staying at home to avoid exposure to COVID-19, as a larger proportion of the population must work for a daily income (Patel et al., 2020).

We account for a municipality's low access to paved highways or roads (Coneval, 2018). On average, we find that $17 \%$ of the municipality population have inadequate access to paved roads. If municipalities do not access paved highways, they can have a protector barrier to avoid or delay contact to reduce de imported cases, at least in the initial stage. On the contrary, low access to the road can delay prompt attention, and more people can die before reaching a medical center or hospital. On average, municipalities have 3.29 private general hospitals and 2.75 public hospitals. The general municipality mortality rate is an exogenous cross-sectional variation unrelated to the COVID-19 deaths. On average, Mexican municipalities have a mortality rate of $0.56 \%$; in some cities, mortality is as high as $1.2 \%$.

COVID-19 confirmed cases are negatively associated with temperature and positively associated with precipitation or rainfalls (Méndez-Arriaga, 2020). Mexican municipalities reported 35.55 millimeters $(\mathrm{mm})$ of average annual rainfall. Pollution can increase the risk of adverse respiratory and cardiovascular diseases (Domingo and Rovira, 2020). Exposure to air pollutants may complicate the recovery of affected patients and lead to severe damage increasing the risk of mortality. Conticini, Frediani, and Caro (2020) and Frontera et al. (2020) found for the Italian case that pollution is a factor related to the lethality of COVID-19. We include a measure of air quality for every MZ available from the Weather channel. When the value of the index is low, the air quality is better. There is also heterogeneity among MZ. The average air quality is 51.65, while the least polluted city has 20.0, and the most polluted has an index value of 487.

The President's votes account for the population's political inclination as a proxy of the COVID-19 risk perception across municipalities. The President's messages of underestimating the pandemic might influence his supporters to increase exposure. COVID-19 risk perception differs from political inclinations (Bruine de Bruin, Saw, and Goldman, 2020). Barrios and Hochberg (2020) found a difference in response to social distancing behavior between high and low president Donald Trump's voters across USA counties. Adolph et al. (2020) found that republican governors and governors in states with more Trump supporters were slower in adopting social distancing policies. We examine how the Mexican case resembles the USA case as both presidents have underestimated the outbreak's path.

In the first stage of the pandemic, Gunthe and Patra (2020) and Sun et al. (2020) found that the USA had the same risk of having imported COVID-19 cases as Thailand and the United Kingdom. Because of the US's proximity, Mexico could have faced a similar risk of imported COVID-19 unconfirmed cases. High mobility in commercial flights contributes to the local spread and dissemination of COVID-19, as Carmo et al. (2020) found within Brazil's municipalities. Mexico implemented the most stringent measure to close non-essential activities to reduce mobility and exposure from March 23 to May 31. We use the Global Mobility Report by Google (2020) that captures the daily mobility trends on the population at the state level. We calculate that people's 
average mobility in Mexico was reduced in most destinations and increased in residence places, following the recommendation of staying at home. In the first month of the analysis, March 18-April 17 , we observe that the workplaces' mobility was the highest, followed by the grocery stores and pharmacies. As a result of the business lockdown, people reduced their mobility as a preventive measure to reduce the risk of COVID-19 contagion. However, it increased by June 18, particularly in the workplaces.

Objective risk information was scarce in the early development of the pandemic. For the USA case, Bruine de Bruin and Bennett (2020) found that the initial COVID-19 perceived risk of infection and fatalities were lower at the beginning of March than later. According to Fischhoff, Bostrom, and Quadrel (1993), people tend to underestimate the relationship between risk and exposure, especially when they do not understand the frequency of exposure and associated risks.

Findings related to COVID-19 indicate that people can spread the disease without showing any symptom, which increase the number of undocumented infections and confound the risk perception assessment. Massive testing could provide a better approximation to the actual number of the affected by COVID-19. Escudero et al. (2020) and Hasell et al. (2020) coincide that Mexico has a low testing rate. From the data, we can identify the date of infection and the date of showing symptoms, although $\mathrm{Li}$ et al. (2020) estimated that $86 \%$ of the real cases are asymptomatic. We estimate that affected people mostly show symptoms in the same month of the analysis, as Table 1 shows. During the first months of the pandemic, more patients suffered COVID-19 symptoms in the same month, $96.28 \%$, and this percentage reduced to $88 \%$ in the last analyzed month. People reported having more symptoms after May 18-June 17, 36.56\%, and from June 18- July 17, 40.27\%, together accounting for $76.83 \%$. People were more aware of the symptoms as time passed.

Table 1. Relationship between the date of symptoms and date of COVID-19 confirmation

\begin{tabular}{|l|c|c|c|c|c|c|}
\hline & \multicolumn{5}{|c|}{ Date of symptoms } & Contact with \\
another \\
$\begin{array}{l}\text { Date of } \\
\text { confirmation } \\
\text { COVID-19 cases }\end{array}$ & $\begin{array}{l}\text { February 18 } \\
- \text { March 17 }\end{array}$ & $\begin{array}{c}\text { March 18 } \\
\text { - April 17 }\end{array}$ & $\begin{array}{c}\text { April 18 - } \\
\text { May 17 }\end{array}$ & $\begin{array}{c}\text { May 18 - } \\
\text { June 17 }\end{array}$ & $\begin{array}{c}\text { June 18 - } \\
\text { July 17 }\end{array}$ & $\begin{array}{c}\text { Cffected COVID- } \\
\text { 19 patient }\end{array}$ \\
\hline March 18 - April 17 & 3.72 & 96.28 & 0.00 & 0.00 & 0.00 & 24.80 \\
\hline April 18 - May 17 & 0.00 & 6.34 & 93.66 & 0.00 & 0.00 & 26.77 \\
\hline May 18 - June 17 & 0.00 & 0.01 & 9.70 & 90.29 & 0.00 & 31.11 \\
\hline June 18 - July 17 & 0.00 & 0.00 & 0.01 & 11.99 & 88.00 & 31.39 \\
\hline Total with symptoms & 0.14 & 4.54 & 18.48 & 36.56 & 40.27 & \\
\hline
\end{tabular}

Source: Authors' calculation using microdata of Secretaria de Salud (2020a). Over the period, there are 292,196 confirmed cases and 32,882 deaths. It accounts for $65.8 \%$ of total confirmed cases and $78.8 \%$ of total deaths in Mexico. Retrieved from https://www.gob.mx/salud/documentos/datos-abiertos-152127

We can also identify whether a patient knew he/she had contact with another COVID-19 confirmed case. We argue that the awareness of exposure is a more accurate signal of an individual's risk perception. People would take more preventive measures to start early treatment to reduce the chances of dying and isolate to limit disease spreading. 
Data reveal that awareness increased from $24.80 \%$, estimated in the first period analyzed, to $31.39 \%$ at the end of the analyzed period. We infer that most affected patients did not know how they got infected with the COVID-19; perhaps they were in contact with asymptomatic people.

\section{Methodology}

Secretaria de Salud $(2020,2020$ a) publishes a complete dataset of the COVID-19 people treated with information regarding comorbidities, age, sex, and other useful information to assess their risk of dying. We aggregate this information to the municipality level since our objective is to obtain factors inherent to the cities that help to understand the pandemic's evolution.

We evaluate the first stage of the pandemic outbreak in Mexico by analyzing monthly municipality panel data for four periods (March 18-April 17, April 18-May 17, May 18-June 17, and June 18-July 17). We argue that the pandemic's first response was critical to understand the outbreak's path. Based on the WHO's epidemiological measurement (2020, May 12), we infer that a low elasticity value of deaths to confirmed cases indicates a relatively controlled outbreak. A high value suggests that the COVID-19 pandemic was near to be out of control.

There are observed and unobserved factors, $\varepsilon_{i t}$, related to the confirmed cases and deaths, which could be associated with the exogenous control variables. Because of the short span of the analysis, we have time-invariant observable characteristics of the analyzed cities, and some of them are available in different aggregation levels. A panel data or longitudinal study is preferred to account for the heterogeneity across the municipalities over time. We apply the Hausman and Taylor (1981) methodology because it allows correlation among some of the regressors and the individual or specific effect. For identification, it requires finding instruments, which are time-varying and timeinvariant exogenous variables in the estimation not correlated to the unobserved specific error term. Thus, we follow Hausman and Taylor (1981) to estimate the elasticity of deaths to confirmed cases by separating the observed variables into four groups: exogenous time-varying, $X_{1 i t}$, endogenous time-varying, $X_{2 i t}$, exogenous time-invariant, $Z_{1 i}$, and endogenous time-invariant, $Z_{2 i}$. The equation to estimate is:

$$
\ln \left(\text { deaths }_{i t}\right)=X_{1 i t} \beta_{1}+X_{2 i t} \beta_{2}+Z_{1 i} \delta_{1}+Z_{2 i} \delta_{2}+v_{i}+\varepsilon_{i t}
$$

We argue that COVID-19 confirmed cases, poverty level, the President's percentage of votes, and the FA group's binary variable are endogenous to the unobserved specific disturbances at the municipality level. On the one hand, COVID-19 confirmed cases have a measurement error to underreport cases. On the other hand, a selectivity bias might exist if some municipalities detect more cases than others due to a more sensible public health policy to detect cases. Also, people follow preventing measures or other unobservable factors related to the real number of COVID-19 cases. High poverty levels may induce a less protective behavior because of the need to obtain a daily income. They face food insecurity that affects health outcomes making their immune system weaker (Gowda, Hadley, and Aiello, 2012). We use political preferences that polarize federal and local governments' strategies in the pandemic's early stage. We test whether the President's supporters followed his implicit 
message of initially underestimate the pandemic. High risk-averse individuals might avoid their exposure to COVID-19. We also account for the local governments' management of the crisis and how people in the FA states comply with the health measurements recommended to reduce deaths and cases relative to the national strategy. Two endogenous variables show variation over time: COVID19 confirmed cases and FA group, a binary variable that changes as more state governments join the FA group. Poverty and the percentage of votes are endogenous time-invariant variables.

\section{Results}

To test the efficiency of the models between fixed effects, random effects and Hausman-Taylor, we show the Hausman test in Table A2 in the annex. The Hausman-Taylor estimation is a panel estimation of random effects with instrumental variables (Baltagi, Bresson, and Pirotte, 2003; McPherson and Trumbull, 2008). The null hypothesis in the Hausman test of comparing fixed effects and random effects does not longer holds if there is a correlation between the observable and unobservable variables, which would imply that the random effects methodology is not recommended.

In Table 2 we show one model specification as baseline and the differences arise because of the combination of instruments and the assumption of endogenous variables. Table A2 shows that in all models, the Hausman test indicates that fixed-effects is the consistent methodology compared to random effects. On the one hand, the problem with fixed effects is that it eliminates the variables that do not change over time and that in the case of the article are relevant. On the other hand, random effects need a strong assumption of no correlation of any exogenous variables and the unobservables. Therefore, the relevant comparison is fixed effects and Hausman-Taylor. It is shown in the third column of Table A2. The results indicate that both methodologies are equally efficient. In order to keep the endogenous and exogenous variables that do not change over time, the Hausman-Taylor methodology was preferred, taking advantage of the fact that they do not impose assumptions such as the fixed effects methodology, where all the variables are correlated with the unobservable.

The last two columns in Table A2 show the overidentification test; we use the Sargan-Hansen test developed by Schaffer and Stillman (2006). To select the models to be shown in Table 2 and Table 3 , we ran forty-two Hausman-Taylor models and test whether the combinations of instruments and endogenous variables were valid. Firstly, we test exactly identified models assuming respectively as endogenous variable: poverty, cases, FA and votes. Secondly, we ran models with two endogenous variables. Thirdly, we define three, and then the four variables as endogenous. The overidentification test provided evidence to select only the instruments' model combinations that did not reject the cross-section and time series model's null hypothesis of adequate instruments to account for the endogenous variables' set. In other words, in each model estimated we assumed that some exogenous variables might be endogenous, and we test whether the excluded instruments are valid instruments, that are uncorrelated with the error term and correctly excluded from the equation. We only show the models that satisfy the instruments validity test. 
Table 2. Hausman-Taylor panel data results of the first stage of COVID-19 in Mexico

\begin{tabular}{|c|c|c|c|c|c|c|c|}
\hline $\begin{array}{l}\text { Models } \\
\text { combination } \\
\text { with the } \\
\text { Endogenous } \\
\text { Variables } \\
\text { (shaded) }\end{array}$ & $\ln$ (poverty) & $\begin{array}{l}\ln \text { (poverty) } \\
\& \ln \text { (cases) }\end{array}$ & $\begin{array}{c}\ln \text { (poverty) } \\
\& \ln \text { (votes) } \\
\text { M3 }\end{array}$ & $\begin{array}{c}\ln \text { (poverty) } \\
\text { \& FA } \\
\text { M4 }\end{array}$ & $\begin{array}{c}\ln (\text { poverty) } \\
\& \ln \text { (case) } \\
\& \ln (\text { votes) } \\
\text { M5 }\end{array}$ & $\begin{array}{c}\ln \text { (poverty) } \\
\& \ln \text { (cases) } \\
\text { \& FA } \\
\text { M6 }\end{array}$ & $\begin{array}{c}\ln \text { (poverty) } \\
\& \ln \text { (votes) } \\
\text { \& FA } \\
\text { M7 }\end{array}$ \\
\hline \multicolumn{8}{|c|}{ Time-varying exogenous $\left(X_{1 i t}\right)$} \\
\hline \multirow[t]{2}{*}{$\begin{array}{l}\text { mobility } \\
\text { parks }\end{array}$} & 0.00522 & 0.00418 & 0.00708 & 0.00656 & 0.00638 & 0.00540 & $0.00725^{*}$ \\
\hline & $(0.00420)$ & $(0.00460)$ & $(0.00435)$ & $(0.00419)$ & $(0.00475)$ & $(0.00462)$ & $(0.00434)$ \\
\hline mobility & $0.0419^{* * *}$ & $0.0417^{* * *}$ & $0.0487^{* * *}$ & $0.0461^{* * *}$ & $0.0478^{* * *}$ & $0.0451^{* * *}$ & $0.0491^{* * *}$ \\
\hline $\begin{array}{l}\text { residence } \\
\text { place }\end{array}$ & $(0.0113)$ & $(0.0119)$ & $(0.0120)$ & $(0.0115)$ & $(0.0124)$ & $(0.0121)$ & $(0.0120)$ \\
\hline \multirow{2}{*}{ hospitalized } & $0.00265^{* * *}$ & $0.00253^{* * *}$ & $0.00250^{* * *}$ & $0.00277^{* * *}$ & $0.00245^{* * *}$ & $0.00264^{* * *}$ & $0.00255^{* * *}$ \\
\hline & $(0.000695)$ & $(0.000719)$ & $(0.000710)$ & $(0.000684)$ & $(0.000720)$ & $(0.000707)$ & $(0.000716)$ \\
\hline symptons & $0.0134^{*}$ & $0.0130^{*}$ & $0.0125^{*}$ & $0.0136^{*}$ & $0.0124^{*}$ & $0.0131^{*}$ & $0.0127^{*}$ \\
\hline Mar-Apr & $(0.00722)$ & $(0.00728)$ & $(0.00737)$ & $(0.00718)$ & $(0.00735)$ & $(0.00724)$ & $(0.00737)$ \\
\hline symptons & $0.0126^{*}$ & $0.0120^{*}$ & $0.0118^{*}$ & $0.0126^{*}$ & 0.0116 & $0.0121^{*}$ & $0.0119^{*}$ \\
\hline Apr-May & $(0.00694)$ & $(0.00699)$ & $(0.00707)$ & $(0.00690)$ & $(0.00706)$ & $(0.00696)$ & $(0.00707)$ \\
\hline Apr-May & & & & & & & \\
\hline symptons & $0.0126^{*}$ & $0.0120^{*}$ & $0.0118^{*}$ & $0.0126^{*}$ & 0.0116 & $0.0121^{*}$ & $0.0119^{*}$ \\
\hline May-Jun & $(0.00694)$ & $(0.00699)$ & $(0.00707)$ & $(0.00691)$ & $(0.00706)$ & $(0.00696)$ & $(0.00707)$ \\
\hline symptons & $0.0127^{*}$ & $0.0121^{*}$ & $0.0120^{*}$ & $0.0127^{*}$ & $0.0117^{*}$ & $0.0122^{*}$ & $0.0121^{*}$ \\
\hline Jun-July & $(0.00695)$ & $(0.00700)$ & $(0.00708)$ & $(0.00691)$ & $(0.00707)$ & $(0.00697)$ & $(0.00708)$ \\
\hline \multirow{2}{*}{$\begin{array}{l}\begin{array}{l}\text { exposed to } \\
\text { someone }\end{array} \\
\text { with COVID- } \\
19\end{array}$} & $-0.00108^{* * *}$ & $-0.00120^{* * *}$ & $-0.00121^{* * *}$ & $-0.000988^{* *}$ & $-0.00126^{* * *}$ & $-0.00111^{* * *}$ & $-0.00118^{* * *}$ \\
\hline & $(0.000388)$ & $(0.000401)$ & $(0.000401)$ & $(0.000385)$ & $(0.000407)$ & $(0.000401)$ & $(0.000413)$ \\
\hline \multirow{2}{*}{ age 5-14 } & -0.0179 & -0.0158 & -0.0158 & -0.0185 & -0.0149 & -0.0167 & -0.0162 \\
\hline & $(0.0115)$ & $(0.0116)$ & $(0.0118)$ & $(0.0115)$ & $(0.0118)$ & $(0.0116)$ & $(0.0118)$ \\
\hline \multirow[t]{2}{*}{ age $15-24$} & $-0.0139 *$ & $-0.0138^{*}$ & $-0.0130^{*}$ & $-0.0138^{*}$ & $-0.0131^{*}$ & $-0.0137^{*}$ & $-0.0131^{*}$ \\
\hline & $(0.00760)$ & $(0.00764)$ & $(0.00775)$ & $(0.00756)$ & $(0.00772)$ & $(0.00761)$ & $(0.00775)$ \\
\hline \multirow[t]{2}{*}{ age $25-64$} & $-0.0126^{*}$ & $-0.0119^{*}$ & $-0.0118^{*}$ & $-0.0127^{*}$ & -0.0115 & $-0.0121^{*}$ & $-0.0119^{*}$ \\
\hline & $(0.00698)$ & $(0.00704)$ & $(0.00712)$ & $(0.00695)$ & $(0.00712)$ & $(0.00701)$ & $(0.00713)$ \\
\hline \multirow[t]{2}{*}{ age $65-84$} & -0.0108 & -0.0102 & -0.0101 & -0.0107 & -0.00986 & -0.0102 & -0.0102 \\
\hline & $(0.00761)$ & $(0.00766)$ & $(0.00776)$ & $(0.00758)$ & $(0.00774)$ & $(0.00763)$ & $(0.00776)$ \\
\hline
\end{tabular}




\begin{tabular}{|c|c|c|c|c|c|c|c|}
\hline \multicolumn{8}{|c|}{ Time-invariant exogenous $\left(Z_{1 i}\right)$} \\
\hline \multirow[t]{2}{*}{$\ln$ (pollution) } & $0.260^{* * *}$ & $0.294^{* * *}$ & $0.265^{* * *}$ & $0.238^{* * *}$ & $0.280^{* * *}$ & $0.269^{* * *}$ & $0.259^{* * *}$ \\
\hline & $(0.0710)$ & $(0.0850)$ & $(0.0711)$ & $(0.0684)$ & $(0.0819)$ & $(0.0822)$ & $(0.0720)$ \\
\hline \multirow[t]{2}{*}{$\ln$ (rainfall) } & -0.0714 & -0.0995 & $-0.127^{*}$ & -0.0386 & $-0.135^{*}$ & -0.0652 & -0.116 \\
\hline & $(0.0604)$ & $(0.0738)$ & $(0.0672)$ & $(0.0630)$ & $(0.0743)$ & $(0.0772)$ & $(0.0836)$ \\
\hline \multirow{2}{*}{$\begin{array}{l}\ln (\text { low access } \\
\text { to } \\
\text { paved roads) }\end{array}$} & $-0.0354^{* *}$ & $-0.0390^{* *}$ & $-0.0420^{* * *}$ & $-0.0310^{* *}$ & $-0.0431^{* * *}$ & $-0.0345^{* *}$ & $-0.0406^{* * *}$ \\
\hline & $(0.0138)$ & $(0.0157)$ & $(0.0142)$ & $(0.0135)$ & $(0.0153)$ & $(0.0154)$ & $(0.0154)$ \\
\hline $\begin{array}{l}\ln (\text { General } \\
\text { death }\end{array}$ & $0.197^{* * *}$ & $0.226^{* * *}$ & $0.232^{* * *}$ & $0.196^{* * *}$ & $0.241^{* * *}$ & $0.219^{* * *}$ & $0.230^{* * *}$ \\
\hline Rate) & $(0.0393)$ & $(0.0519)$ & $(0.0438)$ & $(0.0376)$ & $(0.0520)$ & $(0.0506)$ & $(0.0450)$ \\
\hline \multirow{2}{*}{$\begin{array}{l}\text { Private } \\
\text { hospitals }\end{array}$} & -0.00669 & -0.00638 & -0.00663 & $-0.00733^{*}$ & -0.00657 & -0.00701 & -0.00672 \\
\hline & $(0.00449)$ & $(0.00499)$ & $(0.00449)$ & $(0.00429)$ & $(0.00477)$ & $(0.00469)$ & $(0.00445)$ \\
\hline \multirow{2}{*}{ Constant } & $-6.529 * * *$ & $-7.527^{* * *}$ & $-6.522^{* * *}$ & $-5.939^{* * *}$ & $-6.953^{* * *}$ & $-6.808^{* * *}$ & $-6.399^{* * *}$ \\
\hline & $(1.317)$ & $(1.750)$ & $(1.326)$ & $(1.339)$ & $(1.749)$ & $(1.810)$ & $(1.412)$ \\
\hline \multicolumn{8}{|c|}{ Time-varying possibly endogenous $\left(X_{2 i t}\right)$} \\
\hline \multirow{2}{*}{$\ln$ (cases) } & $0.624^{* * *}$ & $0.607^{* * *}$ & $0.607^{* * *}$ & $0.616^{* * *}$ & $0.601^{* * *}$ & $0.603^{* * *}$ & $0.607^{* * *}$ \\
\hline & $(0.0278)$ & $(0.0320)$ & $(0.0297)$ & $(0.0287)$ & $(0.0328)$ & $(0.0325)$ & $(0.0299)$ \\
\hline \multirow{2}{*}{$\begin{array}{l}\text { federalist } \\
\text { Alliance (FA) }\end{array}$} & -0.0972 & -0.0624 & 0.0282 & -0.00740 & 0.0302 & 0.00124 & 0.0386 \\
\hline & $(0.0827)$ & $(0.0910)$ & $(0.107)$ & $(0.109)$ & $(0.108)$ & $(0.111)$ & $(0.116)$ \\
\hline \multicolumn{8}{|c|}{ Time-invariant possibly endogenous $\left(Z_{2 i}\right)$} \\
\hline \multirow[t]{2}{*}{$\ln ($ votes $)$} & $0.281^{*}$ & 0.254 & $0.840^{* *}$ & $0.394^{* *}$ & $0.780^{* *}$ & $0.353^{*}$ & $0.825^{* *}$ \\
\hline & $(0.171)$ & $(0.190)$ & $(0.341)$ & $(0.185)$ & $(0.376)$ & $(0.203)$ & $(0.348)$ \\
\hline \multirow[t]{2}{*}{$\ln$ (poverty) } & $0.986^{* * *}$ & $1.198^{* * *}$ & $1.066^{* * *}$ & $0.839^{* * *}$ & $1.150^{* * *}$ & $1.024^{* *}$ & $1.030^{* * *}$ \\
\hline & $(0.294)$ & $(0.386)$ & $(0.299)$ & $(0.306)$ & $(0.380)$ & $(0.407)$ & $(0.340)$ \\
\hline sigma u & 0266 & 0.437 & 0348 & 0.320 & 0392 & 0.380 & 0329 \\
\hline sigma_e & 0.515 & 0.515 & 0.515 & 0.515 & 0.515 & 0.515 & 0.515 \\
\hline rho & 0.211 & 0.419 & 0.314 & 0.279 & 0.368 & 0.352 & 0.290 \\
\hline $\mathrm{F}$ & 213.0 & 170.0 & 184.7 & 198.3 & 171.6 & 179.1 & 187.4 \\
\hline$\chi^{2}$ & 4472.2 & 3570.6 & 3878.1 & 4164.1 & 3602.9 & 3761.0 & 3935.7 \\
\hline Observations & 893 & 893 & 893 & 893 & 893 & 893 & 893 \\
\hline
\end{tabular}

Source: Authors' calculation using data cited in Table 1 and Secretaria de Salud (2020, 2020a).

Note: Clustered standard errors at the Metropolitan Zone in parentheses. ${ }^{*} \mathrm{p}<0.10,{ }^{* *} \mathrm{p}<0.05,{ }^{* * *} \mathrm{p}<0.01$.

We find that as long as we define the poverty level as endogenous, any instrument combination was valid to account for the endogeneity in the cross-section and time-series models. Intuitively, the poverty level is associated with unobserved factors behind the number of deaths 
across the municipalities. It is challenging to comply with health recommendations when poor people need to work. They have limited health care coverage to get prompt medical consultation and weaker immune systems because of food insecurity. They also fail to keep a social distance from other people as they have to travel on public transportation and live in crowded houses with other family members who also have to go out to work (Patel et al., 2020). These related factors are unobserved in our data. Information and protocols to reduce the risk of contagion might prepare the population to reduce contagion probabilities.

The recommendations were not clear about using the face mask to reduce the risk of contagion. Federal health authorities did not encourage using face masks; however, it was compulsory to use face masks in public places and transportation in some states. From Table 2, we observe that the elasticity of deaths to confirmed cases is lower than one, which does not indicate an uncontrolled pandemic.

The number of associated deaths to confirmed cases is distressing; an increase in ten percent of the confirmed CODIV-19 cases shows an increase of about six percent of deaths associated across the municipalities over Mexico's first stage of the pandemic. The poverty elasticity to deaths raises more concerns because if the poverty level increases by ten percent, the number of associated deaths increases in the range of 8.39 to 11.98 percent. When we assume as endogenous other variables like confirmed cases, percentage of votes, and FA group, the elasticity of poverty to COVID-19 deaths became more elastic.

We also found that the FA binary variable has a non-significant coefficient. On the contrary, the variable that considers the President's supporters has a positive sign in any model specification and significant in all but one model. An increase in ten percent of the percentage of votes shows an increase in the associated deaths from 2.8 to 8.40 percent.

The time-varying exogenous variables included are instruments that let us infer a weak relationship in the mobility to parks and places around the residence to deaths, which coincides with the policy to stay at home and the rising pattern of deaths along the analyzed period. More hospitalized patients associate with more COVID-19 deaths. For an increase of 1,000 patients in hospitals, the deaths increase by about 3 percent.

A primary result is that an increase in the percentage of confirmed cases -who knew had contact with another person affected by COVID-19- reduced the associated deaths. We infer that as they were aware of the risk they faced; they could have medical advice to deal with the disease at the early development of the symptoms. This result is in line with Frischhoff, Bostrom, and Quadrel (1993), who mentioned that a better assessment of people's health risk leads to better decisions and better health outcomes. We also estimate that COVID-19 deaths in younger patients (15 to 64) are lower than those aged 85 and older. Evidence shows that patients aged 65 to 84 have a similar lethality rate than older patients.

The time-invariant exogenous variables let us account for the fixed factors in the municipalities. We find that pollution is positively related to deaths. As the pollution index increases by 10 percent, there is an increase in deaths in the range of 2.38 to 2.94 percent. There is no clear pattern on the rainfalls and the COVID-19 associated deaths, though. We find that increasing the inadequate access to a paved highway or road reduces the deaths. In other words, the most isolated municipalities showed fewer COVID-19 deaths than those with more access to paved highways, 
connectivity, and mobility. This result seems to favor our approach to focus only on urban areas. Municipalities with higher general mortality rates experienced more COVID-19 deaths. Finally, municipalities with more private hospitals show fewer COVID-19 deaths; however, it is statistically significant only in one model.

We ran a robustness check by eliminating some of the time-varying exogenous variables to reduce the number of instruments in the estimation. We use a combined Sargan-Hansen test developed by Schaffer and Stillman (2006) and follow Roodman's (2009) recommendations of the instruments' validity by focusing on p-values in the range of 0.11- 0.25. However, it is not clear the acceptable ranges to consider a p-value non-suspicious.

The results in Table 3 reveal that most of the exogenous variables do not change the sign and significance. However, we observe some changes in the coefficients of the endogenous variables. The elasticity of the deaths to confirmed cases increases to a range of 0.630 to 0.649 . The poverty level elasticity to COVID-19 deaths reduces to a range of 0.38 to 0.714 . The municipalities that are in the FA group show fewer deaths only in one model. Finally, the President's votes percentage is no longer related to the associated COVID-19 deaths. Table 3 shows that the Sargan-Hansen test is in the range of the recommended range of the instruments' validity.

Comparing Table 2 and Table 3, we infer that the estimation with fewer instruments gave pvalues in the range proposed by Roodman (2009). However, we cannot assure whether the estimates with more instruments are inadequate. Baltagi (2005) recommends increasing the number of timevarying exogenous variables relative to endogenous variables to increase the degrees of freedom in the estimations. We noticed, however, that with fewer instruments, there is an increase in $\backslash$ rho, that is, the proportion of the variance due to the unobservable specific error term, v_i. In any case, estimations in both tables present robust evidence on the elasticity of deaths relative to confirmed COVID-19 cases; the responsiveness of deaths to confirmed cases increases in more than half of the confirmed cases.

Table 3. Robustness analysis of Hausman-Taylor panel data models

\begin{tabular}{|c|c|c|c|c|c|}
\hline $\begin{array}{l}\text { Models } \\
\text { combination } \\
\text { with the } \\
\text { Endogenous } \\
\text { Variables (shaded) }\end{array}$ & $\begin{array}{c}\ln \text { (cases) } \\
\text { M8 }\end{array}$ & $\begin{array}{c}\ln \text { (cases) } \\
\& \ln \text { (poverty) } \\
\text { M9 }\end{array}$ & $\begin{array}{c}\ln \text { (cases) } \\
\text { \& FA } \\
\text { M10 }\end{array}$ & $\begin{array}{c}\ln \text { (cases) } \\
\& \ln \text { (poverty) } \\
\text { M11 }\end{array}$ & $\begin{array}{c}\ln \text { (cases) } \\
\& \ln \text { (votes) } \\
\text { M12 }\end{array}$ \\
\hline \multicolumn{6}{|c|}{ Time-varying exogenous $\left(X_{1 i t}\right)$} \\
\hline \multirow[t]{2}{*}{ mobility parks } & 0.00513 & 0.00383 & 0.00648 & 0.00585 & $0.0102^{*}$ \\
\hline & $(0.00390)$ & $(0.00464)$ & $(0.00401)$ & $(0.00526)$ & $(0.00529)$ \\
\hline mobility around & $0.0351^{* * *}$ & $0.0338^{* * *}$ & $0.0383^{* * *}$ & $0.0385^{* * *}$ & $0.0490^{* * *}$ \\
\hline residence place & $(0.00983)$ & $(0.0118)$ & $(0.0100)$ & $(0.0134)$ & $(0.0141)$ \\
\hline \multirow[t]{2}{*}{ hospitalized } & $0.00391^{* * *}$ & $0.00374^{* * *}$ & $0.00391^{* * *}$ & $0.00378^{* * *}$ & $0.00377^{* * *}$ \\
\hline & $(0.000328)$ & $(0.000324)$ & $(0.000328)$ & $(0.000322)$ & $(0.000353)$ \\
\hline exposed to & $-0.000959^{* * *}$ & $-0.000919^{* * *}$ & $-0.000973^{* * *}$ & $-0.000933^{* * *}$ & $-0.000911^{* * *}$ \\
\hline $\begin{array}{l}\text { someone with } \\
\text { COVID-19 }\end{array}$ & $(0.000179)$ & $(0.000181)$ & $(0.000180)$ & $(0.000179)$ & $(0.000189)$ \\
\hline
\end{tabular}




\begin{tabular}{|c|c|c|c|c|c|}
\hline \multicolumn{6}{|c|}{ Time-invariant exogenous $\left(Z_{1 i}\right)$} \\
\hline \multirow[t]{2}{*}{$\ln ($ pollution) } & $0.302^{* * *}$ & $0.377^{* * *}$ & $0.290^{* * *}$ & $0.319^{* *}$ & $0.272^{* * *}$ \\
\hline & $(0.0701)$ & $(0.110)$ & $(0.0706)$ & $(0.124)$ & $(0.0748)$ \\
\hline \multirow[t]{2}{*}{$\ln$ (rainfalls) } & 0.0543 & 0.0719 & 0.0630 & 0.0996 & 0.00297 \\
\hline & $(0.0416)$ & $(0.0776)$ & $(0.0420)$ & $(0.0844)$ & $(0.0686)$ \\
\hline \multirow{2}{*}{$\begin{array}{l}\ln (\text { low access } \\
\text { Paved highway) } \\
\end{array}$} & $-0.0357^{* * *}$ & $-0.0376^{* *}$ & $-0.0341^{* * *}$ & $-0.0313^{*}$ & $-0.0439^{* * *}$ \\
\hline & $(0.0119)$ & $(0.0178)$ & $(0.0119)$ & $(0.0189)$ & $(0.0148)$ \\
\hline \multirow{2}{*}{$\begin{array}{l}\text { Private } \\
\text { hospital } \\
\end{array}$} & 0.00286 & 0.00616 & 0.00285 & 0.00367 & 0.00338 \\
\hline & $(0.00396)$ & $(0.00591)$ & $(0.00397)$ & $(0.00620)$ & $(0.00404)$ \\
\hline \multirow[t]{2}{*}{ Constant } & $-4.539^{* * *}$ & $-5.509^{* * *}$ & $-4.510^{* * *}$ & $-4.388^{*}$ & $-2.920^{*}$ \\
\hline & $(0.778)$ & $(1.724)$ & $(0.778)$ & $(2.273)$ & $(1.669)$ \\
\hline \multicolumn{6}{|c|}{ Time-varying possibly endogenous $\left(X_{2 i t}\right)$} \\
\hline \multirow[t]{2}{*}{$\ln$ (cases) } & $0.647^{* * *}$ & $0.647^{* * *}$ & $0.649^{* * *}$ & $0.647^{* * *}$ & $0.639^{* * *}$ \\
\hline & $(0.0267)$ & $(0.0254)$ & $(0.0267)$ & $(0.0256)$ & $(0.0283)$ \\
\hline Federalist & $-0.146^{*}$ & -0.0995 & -0.0223 & -0.0444 & 0.0354 \\
\hline Alliance (FA) & $(0.0761)$ & $(0.0891)$ & $(0.111)$ & $(0.113)$ & $(0.124)$ \\
\hline \multicolumn{6}{|c|}{ Time-invariant possibly endogenous $\left(Z_{2 i}\right)$} \\
\hline \multirow[t]{2}{*}{$\ln$ (votes) } & 0.0641 & -0.0137 & 0.172 & 0.146 & 1.145 \\
\hline & $(0.157)$ & $(0.237)$ & $(0.172)$ & $(0.307)$ & $(0.894)$ \\
\hline \multirow[t]{2}{*}{$\ln$ (poverty) } & $0.573^{* * *}$ & $0.714^{*}$ & $0.577^{* * *}$ & 0.472 & $0.383^{*}$ \\
\hline & $(0.142)$ & $(0.390)$ & $(0.142)$ & $(0.515)$ & $(0.232)$ \\
\hline sigma_u & 0.304 & 0.571 & 0.304 & 0.494 & 0.309 \\
\hline sigma_e & 0.519 & 0.519 & 0.519 & 0.519 & 0.519 \\
\hline rho & 0.256 & 0.547 & 0.256 & 0.475 & 0.262 \\
\hline $\mathrm{F}$ & 303.2 & 280.8 & 302.8 & 290.8 & 297.5 \\
\hline chi2 & 3637.9 & 3369.6 & 3633.4 & 3489.7 & 3570.5 \\
\hline Observations & 893 & 893 & 893 & 893 & 893 \\
\hline
\end{tabular}

Source: Authors' calculation using data cited in Table 1 and Secretaria de Salud (2020, 2020a).

Note: Clustered standard errors at the Metropolitan Zone in parentheses. ${ }^{*} \mathrm{p}<0.10,{ }^{* *} \mathrm{p}<0.05,{ }^{* * *} \mathrm{p}<0.01$

Our results accounted for the municipalities' heterogeneity and their relationship with the observable and unobservable variables associated with the number of deaths. We found that the unobserved health risk perception is related to the number of deaths. According to Bruine de Bruin and Bunnett (2020), health risk assessment is related to preventive measures. Consistent with Bruine de Bruin, Saw, and Goldman (2020), risk perceptions are associated with political inclinations. Thus, we estimated that more information about exposure reduced the number of deceased, in the range 
of 0.911 and 1.2 percent for every thousand people who knew they had contact with another COVID19 confirmed case. We infer that informed people got an early treatment and followed a more protective behavior, such as isolation, use of face mask, social distance, and other preventive measures associated with reducing the number of deaths.

Political inclination can polarize risk perceptions. On the one hand, we find weak evidence that the Mexican President's initial assessment of underestimating the severity of the COVID-19 is associated to an increase in the number of deceased. On the other hand, the municipalities that are part of the FA group implemented more stringent measures to counterweight the low-risk perceptions that the federal authorities signaled. Therefore, we infer that a more precautionary message was weakly associated with reducing the number of COVID-19 deaths. Following Fischhoff, Bostrom, and Quadrel (1993), effective risk communications can help individuals reduce their health risks. Ineffective communications, by omitting essential information or failing to contradict misconceptions, create confusing and prompt wrong decisions that can exacerbate the health outcomes.

\section{Conclusion}

In this paper, we analyzed the pattern of the COVID-19 evolution over the first four months of the pandemic in Mexico. We hypothesized whether the government's first response was crucial to understanding the development of the outbreak. We estimate longitudinal elasticity of deaths to confirmed COVID-19 cases by accounting for measurement errors and endogeneity. Additionally, we tested whether poverty levels and two political variables identify the unobservable characteristics specific to the municipalities that contain the outbreak in some municipalities relative to others.

We found evidence that confirmed cases and poverty levels are endogenous in either of the model specifications. We estimate that for a ten percent increase of COVID-19 confirmed cases, there is a six percent increase in COVID-19 deaths during the first four months of the pandemic across the municipalities. This number is robust to any specification model. Municipalities with more votes for the President showed an increase in deaths, conditionally to have more instruments. From our results, we infer that political polarization influences the risk perception assessment of the population. In a politically polarized environment, the preventive measures to reduce COVID-19 cases and fatalities are less effective because people make different choices, consistent with Bruine de Bruin, Saw, and Goldman's (2020) evidence. Our contribution is to identify an association between individual and political risk perception to the number of COVID-19 deaths for the Mexican case. We estimate that an increase in the percentage of confirmed cases -who knew had contact with another person affected by COVID-19- reduced the municipalities' associated deaths. Therefore, it is necessary to increase the number of tests. As more informed infected people know their situation, they will take better care of themselves and others.

A future research line is to study the development of the pandemic and its institutional and individual management as new waves have reached. The analysis needs a definition by stages that could be based on mobility trends and restrictions to identify the contagion speed. It would be recommended to apply the same methodology Hausman-Taylor in a full time period of the pandemic, this is because the information continues to be generated, in this way the initial effect of the first four months would be evaluated with a greater temporal context. 


\section{Acknowledgments}

Centro de Investigaciones Económicas at the Facultad de Economía-UANL supported this research as part of the 60th anniversary of its foundation.

We thank Hector Javier Garcia Troncoso, Fernando Marichalar Salinas, and Jose Alberto Mora for their help in the data compilation from several data sources. We also thank Adrian Moral for useful assistance related to style and language.

\section{References}

[1] Adolph, C., Amano, K., Bang-Jensen, B., Fullman, N. \& Wilkerson, J. (2020). Pandemic Politics: Timing State-Level Social Distancing Responses to COVID-19. Journal of Health Politics, Policy, and Law, 8802162. https://doi.org/10.1215/03616878-8802162

[2] Baltagi, B. H., Bresson, G., and Pirotte, A. (2003). Fixed effects, random effects or Hausman-Taylor? Economics Letters, 79(3), 361-369. doi:10.1016/s0165-1765(03)00007-7

[3] Baltagi, B. (2005). Econometric Analysis of Panel Data. John Wiley \& Sons Ltd, England, Third Edition.

[4] Barrios, J. \& Hochberg, Y. (2020). Risk perception through the lens of politics in the time of the COVID19 pandemic. NBER Working Paper No. 27008. Retrieved: https://www.nber.org/papers/w27008.pdf.

[5] Bruine de Bruin, W., and Bennett, D. (2020). Relationships between initial COVID-19 risk perceptions and protective health behaviors: A national survey. American Journal of Preventive Medicine, 59(2), 157-167. https://doi.org/10.1016/j.amepre.2020.05.001

[6] Bruine de Bruin, W., Saw, HW. and Goldman, D.P. (2020). Political polarization in US residents' COVID19 risk perceptions, policy preferences, and protective behaviors. Journal of Risk and Uncertainty. Vol 61, pp. 177-194. https://doi.org/10.1007/s11166-020-09336-3

[7] Carlitz, R. \& Makhura, M. (2021). Life under lockdown: Illustrating tradeoffs in South Africa's response to COVID-19. World Development, 137. https://doi.org/10.1016/j.worlddev.2020.105168

[8] Carmo, R., Nunes, B., Machado, M., Armstrong, A. \& Souza, C. (2020). Expansion of COVID-19 within Brazil: the importance of highways, Journal of Travel Medicine, 27 (5). https://doi.org/10.1093/jtm/taaa106

[9] Chundakkadan, R. \& Ravindran, R. (2020). Information flow and COVID-19 recovery. World Development, 136. https://doi.org/10.1016/j.worlddev.2020.105112

[10] Coneval (2018). Grado de accesibilidad a carretera pavimentada. Documento metodológico. Octubre. Consejo Nacional de Evaluación de la Política de Desarrollo Social. Retrieved: https://www.coneval.org.mx/Medicion/MP/Documents/Accesibilidad_carretera/Documento_metod ologico.pdf

[11] Conticini, E., Frediani, B., \& Caro, D. (2020). Can atmospheric pollution be considered a co-factor in extremely high level of SARS-CoV-2 lethality in Northern Italy? Environmental Pollution, 261. https://doi.org/10.1016/j.envpol.2020.114465

[12] Custom Weather (2020). Satellite-Derived Historical Precipitation Data. Retrieved: https://customweather.com/products/historical-data-analytics/

[13] Datamun Coneval (2020a). Datos del avance municipal 2010. Retrieved: http://sistemas.coneval.org.mx/DATAMUN 
[14] Datamun Coneval (2020b). Datos del avance municipal 2015. Retrieved: http://sistemas.coneval.org.mx/DATAMUN

[15] DOF (2020). ACUERDO número 02/03/20 por el que se suspenden las clases en las escuelas de educación preescolar, primaria, secundaria, normal y demás para la formación de maestros de educación básica del Sistema Educativo Nacional, así como aquellas de los tipos medio superior y superior dependientes de la Secretaría de Educación Pública. Diario Oficial de la Federación. 16/03/2020.

Retrieved

from: https://www.dof.gob.mx/nota_detalle.php?codigo=5589479\&fecha=16/03/2020

[16] Domingo, J. \& Rovira, J. (2020). Effects of air pollutants on the transmission and severity of respiratory viral infections. Environmental Research, 187. https://doi.org/10.1016/j.envres.2020.109650

[17] Escudero, X., Guarner, J., Galindo-Fraga, A., Escudero-Salamanca, M., Alcocer-Gamba, M. \& Del-Río, C. (2020). La pandemia de coronavirus SARS-CoV-2 (COVID-19): situación actual e implicaciones para México. Cardiovasc Metab Sci, 31(Suppl: 3):170-177. https://doi.org/10.35366/93943

[18] Fischhoff, Baruch, Ann Bostrom, and Marilyn Jacobs Quadrel (1993). Risk perception and Communication. Annual Review of Public Health. Vol.14, pp. 183-203. https://doi.org/10.1146/annurev.pu.14.050193.001151

[19] Frontera, A., Cianfanelli, L., Vlachos, K., Landoni, G. \& Cremona, G. (2020). Severe air pollution links to higher mortality in COVID-19 patients: The "double-hit" hypothesis. Journal of Infection, Volume 81, Issue 2, pp. 255-259. https://doi.org/10.1016/j.jinf.2020.05.031

[20] Google (2020). COVID-19 Community Mobility Reports. Retrieved: https://www.google.com/covid19/mobility/ (July 18, 2020)

[21] Gowda, C., Hadley, C. \& Aiello, A. (2012). The Association Between Food Insecurity and Inflammation. in the US Adult Population. American Journal of Public Health, 102 (8), 1579-1586. https://doi.org/10.2105/AJPH.2011.300551

[22] Gunthe, S. \& Patra, S. (2020). Impact of international travel dynamics on domestic spread of 2019-nCoV in India: origin-based risk assessment in importation of infected travelers. Globalization and Health, 16 (45). https://doi.org/10.1186/s12992-020-00575-2

[23] Hausman, J. \& Taylor, W. (1981). Panel Data and Unobservable Individual Effects. Econometrica, 49 (6), 1377-1398. https://doi.org/10.2307/1911406

[24] Hale, T., Angrist, N., Cameron-Blake, E., Hallas, L., Kira, B., Majumdar, S., Petherick, A., Phillips, T., Tatlow, H. \& Webster, S. (2020). Oxford COVID-19 Government Response Tracker, Blavatnik School of Government. Retrieved: www.bsg.ox.ac.uk/covidtracker (October 10, 2020)

[25] Hasell, J., Mathieu, E., Beltekian, D., Macdonald, B., Giattino, C., Ortiz-Ospina, E., Roser, M. \& Ritchie, H. (2020). A cross-country database of COVID-19 testing. Scientific data, 7, 1-7. doi: 10.1038/s41597020-00688-8. (October 15, 2020)

[26] INE (2018). Sistema de Consulta de la Estadística de las Elecciones del Proceso Electoral 2017-2018, Instituto Nacional Electoral. Retrieved: https://siceen.ine.mx:3000/\#/tablas-resultados

[27] INEGI (2018). Sistema Estatal y Municipal de Datos. Estadísticas Vitales. Mortalidad, Defunciones Generales 2017. Retrieved: https://www.inegi.org.mx/rnm/index.php/catalog/407

[28] INEGI-DENUE (2019). Servicios de Salud y Asistencia Social. Decimocuarta edición. November 2019. Retrieved: https://www.inegi.org.mx/rnm/index.php/catalog/587

[29] Lee, D., Heo, K. \& Seo, Y. (2020). COVID-19 in South Korea: Lessons for developing countries. World Development. 135. doi: 10.1016/j.worlddev.2020.105057.

[30] Li, R., Pei, S., Chen, B., Song, Y., Zhang, T., Yang, W. \& Shaman, J. (2020). Substantial undocumented infection facilitates the rapid dissemination of novel coronavirus (SARS-CoV-2). Science, 368. doi: $10.1126 /$ science.abb3221. 
[31] McPherson, M. Q., \& Trumbull, W. N. (2008). Rescuing Observed Fixed Effects: Using the HausmanTaylor Method for Out-of-Sample Trade Projections. The International Trade Journal, 22(3), 315-340. doi:10.1080/08853900802191389

[32] Méndez-Arriaga, F. (2020). The temperature and regional climate effects on communitarian COVID-19 contagion in Mexico throughout phase 1. Science of the total Environment, 735 . doi: https://doi.org/10.1016/j.scitotenv.2020.139560.

[33] Prompetchara, E., Ketloy, C. \& Palaga, T. (2020). Immune responses in COVID-19 and potential vaccines: Lessons learned from SARS and MERS epidemic. Asian Pacific Journal of Allergy and Immunology, 38, 1-9. doi: 10.12932/AP-200220-0772.

[34] Roodman, D. (2009). Practitioners' corner. A Note on the Theme of Too Many Instruments. Oxford Bulletin of Economics and Statistics, 71, 135-158. doi: 10.1111/j.1468-0084.2008.00542.x

[35] Roser, M., Ritchie, H., Ortiz-Ospina, E. \& Hasell, J. (2020). Coronavirus Pandemic (COVID-19). Our World in Data. Retrieved: https://ourworldindata.org/coronavirus. (August 13, 2020).

[36] Schaffer, M. \& Stillman, S. (2006). XTOVERID: Stata module to calculate tests of overidentifying restrictions after xtreg, xtivreg, xtivreg2, xthtaylor, Statistical Software Components S456779, Boston College Department of Economics, revised January $15 \quad 2016$. https://ideas.repec.org/c/boc/bocode/s456779.html

[37] Secretaria de Salud (2020). COVID-19 Mexican general information. Retrieved: https://coronavirus.gob.mx/datos/. (August 3, 2020). https://datos.covid-19.conacyt.mx/

[38] Secretaria de Salud (2020a). Datos Abiertos - Bases Históricas. Dirección General de Epidemiologíahttps://www.gob.mx/salud/documentos/datos-abiertos-bases-historicas-direcciongeneral-de-epidemiologia. (September 28, 2020)

[39] Sun, H., Dickens, B., Chen, M., Cook, A. \& Clapham, H. (2020). Estimating number of global importations of COVID-19 from Wuhan, risk of transmission outside mainland China and COVID-19 introduction index between countries outside mainland China. medRxiv. ppmedrxiv-20024075. https://doi.org/10.1101/2020.02.17.20024075

[40] The Weather Channel (2020). Quality Air Index, search by Metropolitan Zone. May 2020. Retrieved: https://weather.com/weather/today

[41] Time and date (2020). Precipitation data search for every Metropolitan Zone. May 2020. Retrieved: https://www.timeanddate.com/weather

[42] WHO (2020). Coronavirus disease (COVID-19) Weekly Epidemiological Update and Weekly Operational Update. World Health Organization Situation Reports. Retrieved: https://www.who.int/emergencies/diseases/novel-coronavirus-2019/situation-reports

[43] WHO (2020, January 10). Risk communication and community engagement readiness and initial response for novel coronaviruses (nCoV). World Health Organization Interim guidance. License: CC BY-NC-SA 3.0 IGO. WHO reference number: WHO/2019-nCoV/RCCE/2020.1. Retrieve from: https://www.who.int/publications/i/item/risk-communication-and-community-engagementreadiness-and-initial-response-for-novel-coronaviruses-(ncov)

[44] WHO (2020, January 11). Novel Coronavirus (nCoV) v1. Operational Support \& Logistics. Disease Commodity Packages. World Health Organization. Retrieved from: https://www.who.int/emergencies/diseases/novel-coronavirus-2019/technical-guidancepublications

[45] WHO. (2020, April 2). Coronavirus disease 2019 (COVID-19): situation report, 73. World Health Organization. https://apps.who.int/iris/handle/10665/331686

[46] WHO (2020, May 12). Public health criteria to adjust public health and social measures in the context of COVID-19: Annex to considerations in adjusting public health and social measures in the context of 
COVID-19, World Health Organization, $\quad$ May $12, \quad 2020$. https://apps.who.int/iris/handle/10665/332073. License: CC BY-NC-SA 3.0 IGO. Retrieved from: https://apps.who.int/iris/bitstream/handle/10665/332073/WHO-2019-nCoV-

Adjusting_PH_measures-Criteria-2020.1-eng.pdf?sequence=1\&isAllowed=y

[47] Wooldridge, J. (2013). Introductory Econometrics: A Modern Approach, South-Western, Cengage Learning, Fifth Edition. The United States of America.

\section{Annex}

Table A1. Time-invariant characteristics of the Mexican urban municipalities

\begin{tabular}{|c|c|c|c|c|c|c|}
\hline Variable & Mean & $\begin{array}{l}\text { Std. } \\
\text { Dev. }\end{array}$ & Min & Max & Definition & $\begin{array}{c}\text { Database } \\
\text { source }\end{array}$ \\
\hline $\begin{array}{l}\text { Multidimens } \\
\text { ional } \\
\text { poverty }\end{array}$ & 45.20 & 16.12 & 4.4 & 83.3 & $\begin{array}{l}\text { \% population deprived of at least } \\
\text { one of the social rights and } \\
\text { income per capita is lower than } \\
\text { the poverty level, } 2015 \text {. }\end{array}$ & $\begin{array}{l}\text { Datamun } \\
\text { Coneval (2020b). }\end{array}$ \\
\hline $\begin{array}{l}\text { Low access } \\
\text { to paved } \\
\text { roads }\end{array}$ & 17.01 & 25.76 & 0.0 & 100.0 & $\begin{array}{l}\text { \%population in the municipality } \\
\text { relative to the state with } \\
\text { inadequate access to highways } \\
\text { paved, } 2010 .\end{array}$ & $\begin{array}{l}\text { Datamun } \\
\text { Coneval (2020a) }\end{array}$ \\
\hline $\begin{array}{l}\text { Private } \\
\text { hospitals }\end{array}$ & 3.29 & 7.67 & 0.0 & 78.0 & $\begin{array}{l}\text { Average number of private } \\
\text { general hospitals in the } \\
\text { municipality, } 2019 .\end{array}$ & $\begin{array}{l}\text { INEGI-DENUE } \\
(2019)\end{array}$ \\
\hline $\begin{array}{l}\text { General } \\
\text { deaths rate }\end{array}$ & 0.56 & 0.13 & 0.1 & 1.2 & $\begin{array}{l}\text { (General deaths } 2017 \\
\text { /population)*100 }\end{array}$ & INEGI (2018) \\
\hline Pollution $^{*+}$ & 51.65 & 62.97 & 20.0 & 487.0 & $\begin{array}{l}\text { Index of air quality (Weighted } \\
\text { average of primary and additional } \\
\text { pollutants 2020). }\end{array}$ & $\begin{array}{l}\text { The Weather } \\
\text { Channel (2020) }\end{array}$ \\
\hline Rainfalls ${ }^{*+}$ & 35.55 & 16.97 & 0.1 & 61.3 & $\begin{array}{l}\text { Average annual rainfall } 2019 \\
\text { (millimeters) }\end{array}$ & $\begin{array}{l}\text { Custom Weather } \\
(2020) \\
\text { Time and date } \\
(2020)\end{array}$ \\
\hline $\begin{array}{l}\text { President } \\
\text { votes }^{+}\end{array}$ & 56.90 & 11.50 & 19.4 & 86.3 & $\begin{array}{l}\text { (Percentage of votes for President } \\
2018 / \text { total votes)* } 100\end{array}$ & INE (2018) \\
\hline
\end{tabular}

Source: Authors' calculation. Information for 417 urban municipalities and *399 municipalities. +The information is at the Metropolitan zone aggregation.

Table A2. Hausman tests and overidentification tests

\begin{tabular}{|l|c|c|c|c|c|}
\hline \multicolumn{2}{|c|}{ Models } & \multicolumn{2}{c|}{ Hausman test } & \multicolumn{2}{c|}{ Overidentification } \\
\hline $\begin{array}{l}\text { Endogenous } \\
\text { variables } \\
\text { combinations }\end{array}$ & Model & $\begin{array}{l}\text { Fixed effects vs } \\
\text { Random effects }\end{array}$ & $\begin{array}{l}\text { Fixed effects vs } \\
\text { Hausman- } \\
\text { Taylor }\end{array}$ & $\begin{array}{l}\text { Sargan- } \\
\text { Hansen test }\end{array}$ & $\begin{array}{l}\text { Sargan- } \\
\text { Hansen } \\
\text { p-value }\end{array}$ \\
\hline ln(poverty) & M1 & $\begin{array}{c}0.0025 \\
\text { Use fixed effects } \\
\text { Do not use Random } \\
\text { effects }\end{array}$ & $\begin{array}{c}0.7625 \\
\text { Use either one }\end{array}$ & 13.646 & 0.3992 \\
\hline $\ln$ (poverty) \& & M2 & 0.0025 & 0.9613 & 10.476 & 0.5743 \\
\hline
\end{tabular}




\begin{tabular}{|c|c|c|c|c|c|}
\hline $\ln$ (cases) & & $\begin{array}{c}\text { Use fixed effects } \\
\text { Do not use Random } \\
\text { effects }\end{array}$ & Use either one & & \\
\hline $\begin{array}{l}\ln \text { (poverty) \& } \\
\ln \text { (votes) }\end{array}$ & M3 & $\begin{array}{c}0.0025 \\
\text { Use fixed effects } \\
\text { Do not use Random } \\
\text { effects }\end{array}$ & $\begin{array}{c}0.5894 \\
\text { Use either one }\end{array}$ & 9.929 & 0.6222 \\
\hline $\begin{array}{l}\ln \text { (poverty) \& } \\
\text { FA }\end{array}$ & M4 & $\begin{array}{c}0.0025 \\
\text { Use fixed effects } \\
\text { Do not use Random } \\
\text { effects }\end{array}$ & $\begin{array}{c}0.6512 \\
\text { Use either one }\end{array}$ & 13.475 & 0.3335 \\
\hline $\begin{array}{l}\ln \text { (poverty) \& } \\
\ln \text { (case) } \\
\& \ln \text { (votes) }\end{array}$ & M5 & $\begin{array}{c}0.0025 \\
\text { Use fixed effects } \\
\text { Do not use Random } \\
\text { effects }\end{array}$ & $\begin{array}{c}0.9218 \\
\text { Use either one }\end{array}$ & 8.781 & 0.6421 \\
\hline $\begin{array}{l}\ln \text { (poverty) \& } \\
\ln \text { (cases) } \\
\& \mathrm{FA}\end{array}$ & M6 & $\begin{array}{c}0.0025 \\
\text { Use fixed effects } \\
\text { Do not use Random } \\
\text { effects }\end{array}$ & $\begin{array}{c}0.9170 \\
\text { Use either one }\end{array}$ & 11.005 & 0.4429 \\
\hline $\begin{array}{l}\ln \text { (poverty) \& } \\
\ln \text { (votes) } \\
\& \text { FA }\end{array}$ & M7 & $\begin{array}{c}0.0025 \\
\text { Use fixed effects } \\
\text { Do not use Random } \\
\text { effects }\end{array}$ & $\begin{array}{c}0.9019 \\
\text { Use either one }\end{array}$ & 10.358 & 0.4985 \\
\hline \multicolumn{6}{|c|}{ Robustness analysis models } \\
\hline $\ln$ (cases) & M8 & $\begin{array}{c}30.02 \\
\text { Use fixed effects } \\
\text { Do not use Random } \\
\text { effects }\end{array}$ & $\begin{array}{c}0.1153 \\
\text { Use either one }\end{array}$ & 9.089 & 0.1056 \\
\hline $\begin{array}{l}\ln \text { (cases) \& } \\
\ln \text { (poverty) }\end{array}$ & M9 & $\begin{array}{c}30.02 \\
\text { Use fixed effects } \\
\text { Do not use Random } \\
\text { effects }\end{array}$ & $\begin{array}{c}0.7349 \\
\text { Use either one }\end{array}$ & 5.528 & 0.2373 \\
\hline $\begin{array}{l}\ln \text { (cases) } \\
\& \mathrm{FA}\end{array}$ & M10 & $\begin{array}{c}30.02 \\
\text { Use fixed effects } \\
\text { Do not use Random } \\
\text { effects }\end{array}$ & $\begin{array}{c}0.2547 \\
\text { Use either one }\end{array}$ & 6.677 & 0.154 \\
\hline $\begin{array}{l}\ln \text { (cases) } \\
\& \ln \text { (poverty) }\end{array}$ & M11 & $\begin{array}{c}30.02 \\
\text { Use fixed effects } \\
\text { Do not use Random } \\
\text { effects }\end{array}$ & $\begin{array}{c}0.7535 \\
\text { Use either one }\end{array}$ & 5.192 & 0.1583 \\
\hline $\begin{array}{l}\ln \text { (cases) } \\
\& \ln \text { (votes) }\end{array}$ & M12 & $\begin{array}{c}30.02 \\
\text { Use fixed effects } \\
\text { Do not use Random } \\
\text { effects }\end{array}$ & $\begin{array}{c}0.5049 \\
\text { Use either one }\end{array}$ & 5.193 & 0.1582 \\
\hline
\end{tabular}

Source: Authors' calculation. First column shows the endogenous variables combinations to each model presented in Table 2 and Table 3. The Hausman test critical values (Prob>chi2) are the same in models M1-M7 because it is the same base model estimated by fixed or random effects. However, models differ with the Hausman-Taylor estimation because of the endogenous and instrumental variable combinations. The same applies to models M8-M12. The overidentification Sargan-Hansen tests show that the models presented have a valid combination of instruments. The robustness models are shown in the specifications M8-M12 and have p-values below 0.25 as Roodman (2009) suggested. 